\title{
Multifactorial mechanisms of the pathogenesis of methicillin-resistant Staphylococcus hominis isolated from bloodstream infections
}

\author{
Ewa Szczuka $[$ - Sylwia Krzymińska $\cdot$ Natalia Bogucka $\cdot$ Adam Kaznowski
}

Received: 18 July 2017 / Accepted: 15 December 2017/Published online: 20 December 2017

(C) The Author(s) 2017. This article is an open access publication

\begin{abstract}
Staphylococcus hominis is a species of the coagulase-negative staphylococci. It has been designated as a potential pathogen but so far the pathogenic mechanisms of this bacterium have not been determined. We studied 30 clinical isolates of methicillinresistant $S$. hominis, which were previously examined for biofilm forming properties. The results of this study revealed that all these $S$. hominis strains had the ability to adhere to HeLa cells. Over $40 \%$ of the $S$. hominis strains invaded epithelial cells. The invasion index ranged from 0 to $41.5 \%$. All isolates exhibited the cytotoxic activity of extracellular factors, which caused the destruction of epithelial cells. More than $90 \%$ of these methicillin-resistant strains contained at least one aminoglycosides resistance gene. The $\operatorname{ant}\left(4^{\prime}\right)-I$ gene was found in $63 \%$ of the isolates, $\operatorname{aac}\left(6^{\prime}\right) / \operatorname{aph}\left(2^{\prime \prime}\right)$ in $20 \%$ and $\operatorname{aph}\left(3^{\prime}\right)$-IIIa in $47 \%$. Two strains were assigned to SCCmec type VIII and three to SCCmec type III. The remaining isolates (83\%) harboured a non-typeable SCCmec type. The mec complex A was predominant in this species. The results indicate that the pathogenicity of $S$. hominis may be multifactorial, involving adhesion, invasion
\end{abstract}

E. Szczuka $(\bowtie) \cdot$ S. Krzymińska · N. Bogucka •

A. Kaznowski

Department of Microbiology, Faculty of Biology, Institute of Experimental Biology, Adam Mickiewicz University in Poznań, ul. Umultowska 89, 61-614 Poznań, Poland

e-mail: ewasz@amu.edu.pl and the activity of extracellular toxins, which cause damage to the host epithelium.

Keywords Staphylococcus hominis - Antibiotic resistance genes · Adhesion - Invasion · Cytotoxicity

\section{Introduction}

Staphylococcus hominis is a species of the Coagulasenegative staphylococci (CoNS). Among CoNS, S. hominis is one of the three most frequently identified isolates recoverable from the blood of hospitalised patients (Spanu et al. 2003; Chaves et al. 2005; Becker et al. 2014). These bacteria are recognised as potentially opportunistic pathogens and may cause bloodstream infections, endocarditis, peritonitis, osteomyelitis, bone and joint infections (d'Azevedo et al. 2008; Sorlozano et al. 2010; Ruiz de Gopegui et al. 2011; Becker et al. 2014). The majority of the infections caused by staphylococci are associated with the use of indwelling medical devices (Rodhe et al. 2006; Sorlozano et al. 2010; Mendoza-Olazarán et al. 2013). The exact mechanisms of S. hominis pathogenicity have still not been determined.

The rise of drug-resistant strains is a serious problem in the treatment of infections caused by $S$. hominis (Sorlozano et al. 2010; Ruiz de Gopegui et al. 2011; Szczuka et al. 2016a, b). Methicillin-resistance is associated with the presence of the mecA gene, which is located on a mobile genetic element, called 
the staphylococcal cassette chromosome (SCCmec). The mecA gene encodes a penicillin-binding protein (PBP2a). As a result of mecA expression, beta-lactam antibiotics are not effective against MRSA. To date, eleven SCCmec types have been described, based on the class of the mec gene complex (A-E) and the $c c r$ gene complex (IWG 2009). The $c c r$ genes encoding recombinases responsible for the integration and excision of SCCmec from the chromosome. According to the literature, SCCmec elements, in CoNS, are highly diverse in their genetic content. The SCCmec can harbour multiple $\mathrm{ccr}$ allotypes and/or the untypeable $c c r$ allotype, and a new combination of the mec complex and the ccr complex (IWG 2009; Ruppé et al. 2009; Mendoza-Olazarán et al. 2013; Shore and Coleman 2013; Bouchami et al. 2012; Szczuka et al. 2016a, b). Methicillin-resistant staphylococci are most often resistant to a number of widely used antimicrobial agents. For this reason, vancomycin is usually the antibiotic of choice in the treatment of staphylococcal infections. When combination therapy is required, aminoglycosides are used, because of their synergistic bactericidal effect in combination with vancomycin. Resistance to aminoglycosides is usually due to drug inactivation by cellular aminoglycosides-modifying enzymes (AMEs). The bifunctional enzyme AAC $\left(6^{\prime}\right) /$ $\operatorname{APH}\left(2^{\prime \prime}\right)$ encoded by the gene $\operatorname{aac}\left(6^{\prime}\right)$-Ie- $\operatorname{aph}\left(2^{\prime \prime}\right)$-Ia and located on transposon Tn4001, modifies all clinically available aminoglycosides, except streptomycin (Ramirez and Tolmasky 2010). The APH $\left(3^{\prime}\right)$ III enzyme encoded by the $a p h\left(3^{\prime}\right)$-III $a$ gene mediates resistance to kanamycin, neomycin and amikacin. The ANT $\left(4^{\prime}\right)$-I enzyme encoded by the ant $\left(4^{\prime}\right)$-I $a$ gene and occurring on plasmid pUB110, inactivates tobramycin, kanamycin, neomycin and amikacin (Ramirez and Tolmasky 2010; Wendlandt et al. 2013).

In this study, we analysed mechanisms of $S$. hominis virulence. Moreover, the frequency of antibiotic resistance genes and the diversity of the SCCmec types were also determined.

\section{Materials and methods}

\section{Bacterial strains}

Thirty strains isolated from the blood of hospitalised patients were regarded as the causative agents of blood stream-infections (at least two blood cultures taken from separate vein puncture were positive). Patients were treated in the Intensive Care Unit, Neonatal Unit and Orthopedic Ward. Strains were identified using a VITEK 2 system (bioMérieux, France). Isolates were stored at $-70{ }^{\circ} \mathrm{C}$. Previously, these strains were tested for biofilm forming properties (Szczuka et al. 2015). Resistance to methicillin was determined by a cefoxitin disc test.

Epithelial cell line

Human epithelial cells from cervix (HeLa cells) were kindly provided from Department of Molecular Virology from Adam Mickiewicz University in Poznań, Poland. The cells were cultivated in RPMI with $5 \%$ fetal bovine serum (FBS, Gibco) and $2 \mathrm{mM}$ glutamine (Difco), $50 \mathrm{Iu} / \mathrm{ml}$ penicillin, $100 \mu \mathrm{g} / \mathrm{ml}$ streptomycin (Nawrot et al. 2010).

\section{Bacterial adhesion and invasion}

Adhesion and invasion ability were performed in a quantitative assay using the gentamicin/lysostaphin protection method, with modifications (Krzymińska et al. 2012a, b, 2015). For the analysis of bacterial adhesion, the infected HeLa cells were lysed using $0.1 \%$ Triton $\mathrm{X}-100$. The total of adherent and invasive bacteria was determined by plating serial dilutions of the lysates on BHI agar. Adherence was expressed as an index, which was designated as a number of colony factor units (CFU) of the associated bacteria, per $1 \mathrm{ml}$ $\left(1 \times 10^{6}\right)$ cells. For the assessment of the bacterial invasion of $\mathrm{HeLa}$ cells, the infected cells were incubated for $2 \mathrm{~h}$ with RPMI, with $300 \mu \mathrm{g} / \mathrm{ml}$ of gentamicin (Krka) and $100 \mu \mathrm{g} / \mathrm{ml}$ of lysostaphin (Sigma) to kill extracellular bacteria. Lysostaphin is unable to enter eukaryotic cells and also gentamicin does not penetrate eukaryotic cells and is effective in eradicating extracellular bacteria, even those with aminoglycoside resistance. After three washes with PBS, the cells were lysed with Triton X-100 and bacterial counts were determined by plating serial dilutions of the lysates on BHI agar. Bacterial invasion was expressed as an index that represented the percentage of invaded bacteria, in comparison to the number of adhered ones, per $10^{6}$ of cells. Escherichia coli $\mathrm{K}-12$ C600 strain was used as the negative control, whereas Yersinia enterocolitica $\mathrm{O}: 8 / 1 \mathrm{~B}$ was used as a positive control in adhesion and invasion tests. 
Cytotoxic assay

Bacteria were grown overnight in TSB at $37{ }^{\circ} \mathrm{C}$, for $24 \mathrm{~h}$ on a rotary shaker. Next, the cultures were centrifuged, at $2000 \mathrm{xg}$, for $30 \mathrm{~min}$ and sterilised through $0.45 \mu \mathrm{m}$ PVGF-membrane filters (Roth). Two-fold dilutions (from 1:2 to 1:512) of supernatants were prepared, in phosphate buffered saline (PBS, Biomed). They were added to the HeLa cell monolayer and incubated for $24 \mathrm{~h}$. The effect of extracellular toxins was expressed as a cytotoxic index and assessed as the reciprocal of the highest dilution of the culture filtrates, which produced a cytopathic effect that was observed under an inverted microscope (Krzymińska et al. 2012a, b). As a negative control, cells treated with non-pathogenic E. coli K12C600 filtrate were used.

\section{Statistical analysis}

Data on adhesion, invasion and cytotoxic indexes are presented as mean \pm standard deviations (SD); they represent two independent experiments, performed in triplicate. A one-way analysis of variance ANOVA with Tukey's post hoc test, was performed. Linear regression analysis was used to examine the pairwise correlation between adhesion, invasion and cytotoxic indexes, and a Pearson correlation coefficient was determined. $\mathrm{p}$ values of $<0.05$ were considered statistically significant.

\section{SCCmec typing}

Genomic DNA was isolated from isolates using a Genomic DNA Plus kit (A\&A Biotechnology, Poland). SCCmec types were identified using multiplex PCR (Zhang et al. 2005). Moreover, detection of ccrAB4 was performed by PCR using primers described by Oliviera et al. (2006). Amplification products were electrophoresed in a $1.5 \%$ agarose gel. Gels were stained with ethidium bromide, visualised under a UV light transilluminator, and documented with a V.99 Bio-Print system (Vilber Lourmat, Torcy, France).
Detection of AME resistance genes

For the detection of resistance genes: $\operatorname{aac}\left(6^{\prime}\right) / \operatorname{aph}\left(2^{\prime \prime}\right)$,

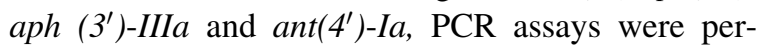
formed (Ardic et al. 2006).

\section{Results}

Staphylococcus hominis adhesion and invasion of human epithelial cells

All S. hominis strains had the ability to adhere to human epithelial cells (Table 1). The adhesion index ranged from $4 \times 10^{5}$ to $5.9 \times 10^{8} \mathrm{CFU} / \mathrm{ml}$. The highest index, from $1.4 \times 10^{8}$ to $5.9 \times 10^{8} \mathrm{CFU} / \mathrm{ml}$, was evident for four isolates (13\%). The lowest index, equal to $4 \times 10^{5} \mathrm{CFU} / \mathrm{ml}$, was observed in one strain (1\%). The negative control, E. coli K12C600 showed an adhesion index of $1.1 \times 10^{2} \mathrm{CFU} / \mathrm{ml}$, whereas that of $Y$. enterocolitica $\mathrm{O}: 8 / 1 \mathrm{~B}$ (positive control) was $2.6 \times 10^{7} \mathrm{CFU} / \mathrm{ml}$. Thirteen S. hominis strains (43\%) exhibited the ability to invade epithelial cells (Table 1). The invasion indices ranged from 0 to $42 \%$. The highest invasive ability, with an index that ranged from 31 to $42 \%$ was observed for five isolates $(17 \%)$. The index of $Y$. enterocolitica $\mathrm{O}: 8 / 1 \mathrm{~B}$ reached $57.3 \%$. The nonpathogenic E. coli K12C600 strain did not demonstrate any invasion of epithelial cells.

Extracellular cytotoxic activity

All S. hominis strains demonstrated activity of extracellular toxins (Table 1). The strains caused a cytopathic effect, which was observed as a rounding off of the HeLa cells. The cytotoxicity titres ranged from 1 to 107. The highest effect, titres $\geq 70$, was observed for eight strains (27\%), whereas the lowest cytotoxicity, in the range from titre 1 to 5 was observed for 16 isolates (53\%). The E. coli K-12 C600 strain was not cytotoxic to epithelial cells.

Analysis of SCCmec structure

All $S$. hominis isolates carried mecA, as detected by PCR. Three strains were assigned to SCCmec type III, containing mec complex A and ccrAB3. Two strains harboured SCCmec type VIII i.e. mec complex A and ccrAB4. The remaining isolates $(83 \%)$ harboured the 
Table 1 Adhesion, invasion and cytotoxic indices of $S$. hominis strains and presence of antibiotic resistance genes as well diversity of the SCCmec element

\begin{tabular}{|c|c|c|c|c|c|c|c|c|c|c|}
\hline \multirow{2}{*}{$\begin{array}{l}\text { Strain } \\
\text { no. }\end{array}$} & \multirow{2}{*}{$\begin{array}{l}\text { Adhesion index } \\
\left(\times 10^{7}\right)\end{array}$} & \multirow{2}{*}{$\begin{array}{l}\text { Invasion } \\
\text { index }(\%)\end{array}$} & \multirow{2}{*}{$\begin{array}{l}\text { Cytotoxic } \\
\text { index (titre) }\end{array}$} & \multirow{2}{*}{$\begin{array}{l}\text { MecA } \\
\text { gene }\end{array}$} & \multicolumn{3}{|c|}{ SCCmec type } & \multicolumn{3}{|c|}{ AME resistance genes } \\
\hline & & & & & $\begin{array}{l}\text { Mec } \\
\text { class }\end{array}$ & $\begin{array}{l}\mathrm{Ccr} \\
\text { type }\end{array}$ & $\begin{array}{l}\text { SCCmec } \\
\text { type }\end{array}$ & $\begin{array}{l}\operatorname{Aac}\left(6^{\prime}\right) / \\
\operatorname{aph}\left(2^{\prime \prime}\right)\end{array}$ & $\begin{array}{l}\text { Aph } \\
\left(3^{\prime}\right)-I I I a\end{array}$ & $\begin{array}{l}\operatorname{Ant}\left(4^{\prime}\right)- \\
I a\end{array}$ \\
\hline $\begin{array}{l}\text { MPU } \\
\text { Sh13 }\end{array}$ & $0.04 \pm 0.03^{\mathrm{a} .}$ & $17.9 \pm 8.7^{\mathrm{b}}$ & $53.3 \pm 18.5^{\mathrm{c}}$ & + & A & ND & NT & - & + & + \\
\hline $\begin{array}{l}\text { MPU } \\
\text { Sh16 }\end{array}$ & $0.11 \pm 0.07$ & $29.5 \pm 21.4$ & $102.1 \pm 73.9$ & + & B & ND & NT & + & + & - \\
\hline $\begin{array}{l}\text { MPU } \\
\text { Sh30 }\end{array}$ & $0.12 \pm 0.06$ & 0 & $1.3 \pm 0.6$ & + & A & ND & NT & + & - & - \\
\hline $\begin{array}{l}\text { MPU } \\
\text { Sh26 }\end{array}$ & $0.16 \pm 0.12$ & $15.6 \pm 9.7$ & $5.3 \pm 2.3$ & + & A & $\operatorname{ccr} A B 3$ & III & + & - & + \\
\hline $\begin{array}{l}\text { MPU } \\
\text { Sh27 }\end{array}$ & $0.36 \pm 0.19$ & $31.4 \pm 27.8$ & $85.3 \pm 36.9$ & + & $\mathrm{A}$ & ND & NT & - & - & + \\
\hline $\begin{array}{l}\text { MPU } \\
\text { Sh28 }\end{array}$ & $0.40 \pm 0.17$ & 0 & $37.3 \pm 24.4$ & + & A & $\operatorname{ccrAB} 4$ & VIII & - & + & + \\
\hline $\begin{array}{l}\text { MPU } \\
\text { Sh17 }\end{array}$ & $0.43 \pm 0.25$ & $35.4 \pm 9.6$ & $104.7 \pm 36.9$ & + & A & ND & NT & - & - & + \\
\hline $\begin{array}{l}\text { MPU } \\
\text { Sh11 }\end{array}$ & $1.37 \pm 0.74$ & 0 & $1.7 \pm 0.6$ & + & $\mathrm{A}$ & ND & NT & - & - & + \\
\hline $\begin{array}{l}\text { MPU } \\
\text { Sh22 }\end{array}$ & $1.43 \pm 0.80$ & 0 & $2.7 \pm 1.1$ & + & A & ND & NT & - & + & - \\
\hline $\begin{array}{l}\text { MPU } \\
\text { Sh21 }\end{array}$ & $1.90 \pm 1.25$ & 0 & $4.7 \pm 3.1$ & + & B & ND & NT & - & - & - \\
\hline $\begin{array}{l}\text { MPU } \\
\text { Sh15 }\end{array}$ & $2.67 \pm 0.74$ & 0 & $1.7 \pm 0.6$ & + & A & ND & NT & - & + & - \\
\hline $\begin{array}{r}\text { MPU } \\
\text { Sh5 }\end{array}$ & $3.77 \pm 1.68$ & 0 & $1.3 \pm 0.6$ & + & A & ND & NT & + & + & + \\
\hline $\begin{array}{l}\text { MPU } \\
\text { Sh20 }\end{array}$ & $4.13 \pm 1.93$ & 0 & $2.3 \pm 0.5$ & + & A & $\operatorname{ccr} A B 3$ & III & - & + & - \\
\hline $\begin{array}{l}\text { MPU } \\
\text { Sh29 }\end{array}$ & $4.57 \pm 1.05$ & 0 & $1.3 \pm 0.6$ & + & A & ND & NT & - & - & + \\
\hline $\begin{array}{l}\text { MPU } \\
\text { Sh14 }\end{array}$ & $4.77 \pm 1.95$ & $21.6 \pm 13.9$ & $37.3 \pm 24.4$ & + & B & ND & NT & + & - & + \\
\hline $\begin{array}{r}\text { MPU } \\
\text { Sh8 }\end{array}$ & $4.95 \pm 2.32$ & 0 & $9.3 \pm 6.1$ & + & A & ND & NT & - & - & + \\
\hline $\begin{array}{l}\text { MPU } \\
\text { Sh18 }\end{array}$ & $4.97 \pm 1.39$ & $37.2 \pm 48.2$ & $106.7 \pm 36.9$ & + & A & $\operatorname{ccr} A B 4$ & VIII & - & + & - \\
\hline $\begin{array}{l}\text { MPU } \\
\text { Sh12 }\end{array}$ & $5.07 \pm 2.15$ & $33.8 \pm 31.9$ & $74.7 \pm 48.9$ & + & A & ND & NT & - & + & + \\
\hline $\begin{array}{l}\text { MPU } \\
\text { Sh23 }\end{array}$ & $6.03 \pm 1.50$ & 0 & $3.3 \pm 1.4$ & + & B & ND & NT & + & - & + \\
\hline $\begin{array}{l}\text { MPU } \\
\text { Sh25 }\end{array}$ & $6.53 \pm 0.86$ & 0 & $2.3 \pm 1.5$ & + & A & ND & NT & - & + & - \\
\hline $\begin{array}{l}\text { MPU } \\
\text { Sh19 }\end{array}$ & $6.63 \pm 2.41$ & $41.7 \pm 29.3$ & $105.3 \pm 36.9$ & + & A & ND & NT & - & - & - \\
\hline $\begin{array}{l}\text { MPU } \\
\text { Sh10 }\end{array}$ & $7.73 \pm 1.62$ & $21.3 \pm 19.8$ & $37.3 \pm 24.4$ & + & A & ccrAB3 & III & - & - & + \\
\hline $\begin{array}{r}\text { MPU } \\
\text { Sh3 }\end{array}$ & $8.53 \pm 2.05$ & 0 & $2.3 \pm 1.5$ & + & A & ND & NT & - & + & + \\
\hline
\end{tabular}


Table 1 continued

\begin{tabular}{|c|c|c|c|c|c|c|c|c|c|c|}
\hline \multirow{2}{*}{$\begin{array}{l}\text { Strain } \\
\text { no. }\end{array}$} & \multirow{2}{*}{$\begin{array}{l}\text { Adhesion index } \\
\left(\times 10^{7}\right)\end{array}$} & \multirow{2}{*}{$\begin{array}{l}\text { Invasion } \\
\text { index }(\%)\end{array}$} & \multirow{2}{*}{$\begin{array}{l}\text { Cytotoxic } \\
\text { index (titre) }\end{array}$} & \multirow{2}{*}{$\begin{array}{l}\text { MecA } \\
\text { gene }\end{array}$} & \multicolumn{3}{|c|}{ SCCmec type } & \multicolumn{3}{|c|}{ AME resistance genes } \\
\hline & & & & & $\begin{array}{l}\text { Mec } \\
\text { class }\end{array}$ & $\begin{array}{l}C c r \\
\text { type }\end{array}$ & $\begin{array}{l}\text { SCCmec } \\
\text { type }\end{array}$ & $\begin{array}{l}\overline{A a c}\left(6^{\prime}\right) / \\
\operatorname{aph}\left(2^{\prime \prime}\right)\end{array}$ & $\begin{array}{l}\text { Aph } \\
\left(3^{\prime}\right)-I I I a\end{array}$ & $\begin{array}{l}A n t\left(4^{\prime}\right)- \\
I a\end{array}$ \\
\hline $\begin{array}{r}\text { MPU } \\
\text { Sh1 }\end{array}$ & $9.40 \pm 2.98$ & 0 & $1.3 \pm 0.6$ & + & $\mathrm{A}$ & ND & NT & - & - & + \\
\hline $\begin{array}{r}\text { MPU } \\
\text { Sh4 }\end{array}$ & $9.60 \pm 4.88$ & 0 & $4.0 \pm 2.5$ & + & $\mathrm{C}$ & ND & NT & - & + & - \\
\hline $\begin{array}{r}\text { MPU } \\
\text { Sh6 }\end{array}$ & $9.67 \pm 2.80$ & 0 & $1.7 \pm 0.6$ & + & $\mathrm{B}$ & ND & NT & - & + & + \\
\hline $\begin{array}{r}\text { MPU } \\
\text { Sh7 }\end{array}$ & $14.03 \pm 4.16$ & $17.8 \pm 11.9$ & $74.7 \pm 48.9$ & + & $\mathrm{A}$ & ND & NT & - & - & + \\
\hline $\begin{array}{l}\text { MPU } \\
\text { Sh24 }\end{array}$ & $14.07 \pm 3.20$ & 0 & $2.3 \pm 1.5$ & + & $\mathrm{A}$ & ND & NT & - & - & + \\
\hline $\begin{array}{r}\text { MPU } \\
\text { Sh2 }\end{array}$ & $57.17 \pm 6.88$ & $5.2 \pm 3.8$ & $42.7 \pm 18.5$ & + & $\mathrm{A}$ & ND & NT & - & - & + \\
\hline $\begin{array}{r}\text { MPU } \\
\text { Sh9 }\end{array}$ & $58.90 \pm 15.15$ & $12.7 \pm 10.6$ & $74.7 \pm 48.9$ & + & $\mathrm{A}$ & ccrAB1 & NT & - & + & - \\
\hline
\end{tabular}

All results are the means \pm standard deviation of two separate experiments performed in triplicate

$N D$ not detected, $N T$ non-typeable SCCmec type

${ }^{\text {a }}$ Data are expressed as the mean of total number of adherent bacteria per $1 \mathrm{ml}$ of HeLa cells

${ }^{\mathrm{b}}$ The percentage of invaded bacteria in comparison with the number adhering

${ }^{\mathrm{c}}$ Reciprocal of the highest titre of bacterial culture supernatant that caused destruction monolayer of HeLa cells

non-typeable SCCmec type. One isolate carried ccrABl and the class A mec complex. For $24 S$. hominis isolates, no $c c r$ gene was identified. A high prevalence $(80 \%)$ of the mec complex A was observed in S. hominis. Five strains carried mec complex B, whereas one strain carried the mec complex $\mathrm{C}$.

Resistance to aminoglycosides

Of the 30 methicillin-resistant $S$. hominis isolates, 28 $(93 \%)$ were resistant to aminoglycoside antibiotics. PCR analysis revealed the existence of the ant $\left(4^{\prime}\right)-I a$ gene in $19(63 \%)$ strains, aac $\left(6^{\prime}\right) / a p h\left(2^{\prime \prime}\right)$ in $6(20 \%)$ and $\operatorname{aph}\left(3^{\prime}\right)$-IIIa in $14(47 \%)$ (Table 1). One strain contained three AME genes. Five isolates (17\%) contained two AME genes $\left(\operatorname{ant}\left(4^{\prime}\right)-I a\right.$ and $a p h\left(3^{\prime}\right)$ IIIa), simultaneously. Three $S$. hominis strains carried $\operatorname{aac}\left(6^{\prime}\right) / \operatorname{aph}\left(2^{\prime \prime}\right)$ and $\operatorname{ant}\left(4^{\prime}\right)-I a$, whereas only one isolates harboured $a a c\left(6^{\prime}\right) / a p h\left(2^{\prime \prime}\right)$ and $a p h\left(3^{\prime}\right)$-IIIa. Only two strains did not harbour any AMEs.

\section{Discussion}

Some reports have noted that $S$. hominis is the third most commonly isolated species among CoNS. Nevertheless, the mechanisms of its virulence are not sufficiently understood. Bacterial adherence to epithelia is typically the first, and the essential step in the colonisation of human tissues and the establishment of infections. Bacterial adhesion was studied using only HeLa cells lines, which is a limitation of this work. All S. hominis strains have the ability to adhere to HeLa cells. For 18 isolates $(60 \%)$ the adhesion index was higher than that of the enteroivasive $Y$. enterocolitica $\mathrm{O}: 8 / 1 \mathrm{~B}$ positive control strain. The results are consistent with the prevalence of $S$. hominis strains on epithelia. Bacterial adhesion to host cells is mediated by surface-binding proteins and exopolymers (Otto 2010; Becker et al. 2014). The presence of adhesins in S. hominis strains was not tested, which is a limitation of this work. Our earlier results revealed that all $S$. hominis strains tested in this study harbour the 
icaADBC genes encoding the polysaccharide intercellular adhesin (PIA) (Szczuka et al. 2015).

We observed that $43 \%$ of the S. hominis strains tested had the ability to invade epithelial cells. This could be an important mechanism leading to bacterial evasion of the host's immune defences and infection maintenance. Some CoNS produce multifunctional adhesin/autolysin (AtlE) that binds fibrinogen, fibronectin and vitronectin in the host, extracellular matrix. Becker et al. (2014) suggested that effect of AtlE could be a possible mechanism for CoNS adhesion and the invasion of host cells.

Bacterial pathogens have evolved remarkable mechanisms to efficiently infect host organisms. In this study, we observed that all S. hominis isolates exhibited a cytotoxic effect on human epithelial cells. A statistical analyses demonstrated positive correlations between the invasion and cytotoxic indices $(\mathrm{r}=0.79, \mathrm{p}<0.05)$. It has been demonstrated that $S$. epidermidis strains produce extracellular proteases, metalloproteases, lipases and esterases (Becker et al. 2014). Otto (2012) reported that phenol soluble modulin delta (PSM $\delta$ ) produced by $S$. epidermidis strains is a potent toxin that exhibits a cytotoxic effect on human cells. These enzymes and toxins induced the destruction of host tissues and the facilitation bacterial invasion.

Another aspect examined in our study was resistance to $\beta$-lactams and aminoglycosides i.e. the antibiotics most commonly used to treat staphylococcal infections. These results showed a high prevalence of antibiotic resistance genes, indicating that these strains can be considered as potential reservoirs for these genes in the hospital environment. Importantly, these genes are located on plasmids, transposons and other mobile genetic elements and can be transferred to more pathogenic species. Coexistence of the mecA gene and an AME was detected in $93 \%$ of the $S$. hominis isolates. The most prevalent AME gene was $\operatorname{ant}\left(4^{\prime}\right)-I$, which was found in $73 \%$ of S. hominis isolates. Similar results were obtained in a study by Ida et al. (2001). It was reported that the ant $\left(4^{\prime}\right)$-I gene was the most frequent in MRSA strains isolated in Japan. In contrast to our findings and that of Ida et al. (2001). Ardic et al. (2006) demonstrated in a study carried out on MRSA and CoNS, that the prevalence of the $\operatorname{ant}\left(4^{\prime}\right)-I$ gene was $24 \%$, whereas the most frequently encountered AME gene was aac $\left(6^{\prime}\right) / a p h\left(2^{\prime \prime}\right)$. In this study, $\operatorname{aac}\left(6^{\prime}\right) / a p h\left(2^{\prime \prime}\right)$ was present in only $20 \%$ of the strains tested.

This study highlights the high frequency of the mec complex A in $S$. hominis. The class B mec gene complex was found in only five $S$. hominis strains, whereas only one isolate carried mec complex C. Importantly, we did not identify the $c c r$ genes in most of the isolates. This failure of identification may be due to the existence of novel allotypes with too low homology with the previously described $\mathrm{ccr}$ to be detected by the PCR primers used. We can exclude the possibility of the loss of the $\mathrm{ccr}$ complex from the SCCmec. Only five isolates carried a known SCCmec type, three of them type III and two SCCmec type VIII. Previous studies have also shown that $S$. hominis carries SCCmec type VIII and type III (Bouchami et al. 2011; Zhang et al. 2013). The prevalence of nontypeable SCCmec observed in this study was previously observed in S. hominis (Hanssen and Ericson Sollid 2007; Bouchami et al. 2011; Zhang et al. 2013).

This study provides a new insight into the mechanisms of S. hominis pathogenicity. We demonstrated that these strains have the ability to adhere, invade host cells and cause direct epithelial barrier dysfunction. These mechanisms may result in the spreading of bacteria and the development of invasive diseases. Moreover, the bacteria may act as a reservoir for antibiotic resistance genes in the hospital environment.

Acknowledgements This study was funded by Faculty of Biology of A. Mickiewicz University in Poznań.

Conflict of interest The authors declare no conflict of interest.

Open Access This article is distributed under the terms of the Creative Commons Attribution 4.0 International License (http:// creativecommons.org/licenses/by/4.0/), which permits unrestricted use, distribution, and reproduction in any medium, provided you give appropriate credit to the original author(s) and the source, provide a link to the Creative Commons license, and indicate if changes were made.

\section{References}

Ardic N, Sareyyupoglu B, Ozyurt M, Haznedaroglu T, Ilga U (2006) Investigation of aminoglycoside modifying enzyme genes in methicillin-resistant staphylococci. Microbiol Res 161:49-54

Becker K, Hellmann C, Peters G (2014) Coagulase-negative staphylococci. Clin Microbiol Rev 27:870-926 
Bouchami O, Ben Hassen A, de Lencastre H, Miragaia M (2011) Molecular epidemiology of methicillin-resistant Staphylococcus hominis (MRSHo): low clonality and reservoirs of SCCmec structural elements. PLoS ONE 6:e21940

Bouchami O, Ben Hassen A, de Lencastre H, Miragaia M (2012) High prevalence of mec complex $\mathrm{C}$ and $c c r C$ is independent of SCCmec type V in Staphylococcus haemolyticus. Eur J Clin Microbiol Infect Dis 31:605-614

Chaves F, García-Álvarez M, Sanz F, Alba C, Otero JR (2005) Nosocomial spread of a Staphylococcus hominis subsp. novo-biosepticus strain causing sepsis in a neonatal intensive care unit. J Clin Microbiol 43:4877-4879

d'Azevedo PA, Trancesi R, Sales T, Monteiro J, Gales AC, Pignatari AC (2008) Outbreak of Staphylococcus hominis subsp. novobiosepticus bloodstream infections in Sao Paulo city, Brazil. J Med Microbiol 57:256-257

Hanssen AM, Ericson Sollid U (2007) Multiple staphylococcal cassette chromosomes and allelic variants of cassette chromosome recombinases in Staphylococcus aureus and coagulase-negative staphylococci from Norway. Antimicrob Agents Chemother 51:1671-1677

Ida T, Okamoto R, Shimauchi C, Okubo T, Kuga A, Inoue M (2001) Identification of aminoglycoside-modifying enzymes by susceptibility testing: epidemiology of methicillin-resistant Staphylococcus aureus in Japan. J Clin Microbiol 39:3115-3121

International Working Group on the Classification of Staphylococcal Cassette Chromosome Elements (2009) Classification of staphylococcal cassette chromosome mec (SCCmec): guidelines for reporting novel sccmec elements. Antimicrob Agents Chemother 53:4961-4967

Krzymińska S, Szczuka E, Kaznowski A (2012a) Staphylococcus haemolyticus strains target mitochondria and induce caspase-dependent apoptosis of macrophages. Antonie van Leeuwenhoek 102:611-620

Krzymińska S, Frąckowiak H, Kaznowski A (2012b) Acinetobacter calcoaceticus-baumannii complex strains induce caspase-dependent and caspase-independent death of human epithelial cells. Curr Microbiol 65:319-329

Krzymińska S, Szczuka E, Dudzińska K, Kaznowski A (2015) Virulence and the presence of aminoglycoside resistance genes of Staphylococcus haemolyticus strains isolated from clinical specimens. Antonie van Leeuwenhoek 107:857-868

Mendoza-Olazarán S, Morfin-Otero R, Rodríguez-Noriega E, Llaca-Díaz J, Flores-Treviňo S, Ma González-Gonzálezn G, Villarreal-Treviňo L, Garza- Gonzálezn E (2013) Microbiological and molecular characterization of Staphylococcus hominis isolates from blood. PLoS ONE 8:e61161

Nawrot R, Wołun-Cholewa M, Białas W, Wyrzykowska D, Balcerkiewicz S, Goździcka-Józefiak A (2010) Cytotoxic activity of proteins isolated from extracts of Corydalis cava tubers in human cervical carcinoma cells. BMC Complement Altern Med 10:78

Oliveira DC, Milheiriço C, de Lencastre H (2006) Redefining a structural variant of staphylococcal cassette chromosome mec, SCCmec type VI. Antimicrob Agents Chemother 50:3457-3459

Otto M (2010) Staphylococcus colonization of the skin and antimicrobial peptides. Expert Rev Dermatol 5:183-195
Otto M (2012) Molecular basis of Staphylococcus epidermidis infections. Semin Immunopathol 34:201-214

Ramirez MS, Tolmasky ME (2010) Aminoglycoside modifying enzymes. Drug Resist Update 13:151-171

Rodhe H, Mack D, Christner M, Burdelski Ch, Franke G, Knobloch JK-M (2006) Pathogenesis of staphylococcal device-related infections: from basic science to new diagnostic, therapeutic and prophylactic approaches. Rev Med Microbiol 17:45-54

Ruiz de Gopegui E, Iuliana Marinescu C, Diaz P, Socias A, Garau M (2011) Nosocomial spread of linezolid-resistant Staphylococcus hominis in two hospitals in Majorca. Enferm Infecc Microbiol Clin 29:339-344

Ruppé E, Barbier F, Mesli Y, Maiga A, Cojocaru R, Benkhalfat M, Benchouk S, Hassaine H, Maiga I, Diallo A, Koumaré AK, Ouattara K, Soumaré S, Dufourcq JB, Nareth C, Sarthou JL, Andremont A, Ruimy R (2009) Diversity of staphylococcal cassette chromosome mec structures in methicillin-resistant Staphylococcus epidermidis and Staphylococcus haemolyticus strains among outpatients from four countries. Antimicrob Agents Chemother 53:442-449

Shore C, Coleman DC (2013) Staphylococcal cassette chromosome mec: recent advances and new insights. Int J Med Microb 303:350-359

Sorlozano A, Gutierrez J, Martinez T, Yuste ME, Perez-Lopez JA, Vindel A, Guillen J, Boquete T (2010) Detection of new mutations conferring resistance to linezolid in glycopeptide-intermediate susceptibility Staphylococcus hominis subspecies hominis circulating in an intensive care unit. Eur J Clin Microbiol Infect Dis 29:73-80

Spanu T, Sanguinetti M, Ciccaglione D, D'Inzeo T, Romano L, Leone F, Fadda G (2003) Use of the VITEK 2 system for rapid identification of clinical isolates of staphylococci from bloodstream infections. $J$ Clin Microbiol 41:4259-4263

Szczuka E, Telega K, Kaznowski A (2015) Biofilm formation by Staphylococcus hominis strains isolated from human clinical specimens. Folia Microbiol 60:1-5

Szczuka E, Makowska N, Bosacka K, Słotwińska A, Kaznowski A (2016a) Molecular basis of resistance to macrolides, lincosamides and streptogramins in Staphylococcus hominis strains isolated from clinical specimens. Folia Microbiol 61:143-147

Szczuka E, Krajewska M, Lijewska D, Bosacka K, Kaznowski A (2016b) Diversity of staphylococcal cassette chromosome mec elements in nosocomial multiresistant Staphylococcus haemolyticus isolates. J Appl Genet 57:543-547

Wendlandt S, Feßler AT, Monecke S, Ehricht R, Schwarz S, Kadlec K (2013) The diversity of antimicrobial resistance genes among staphylococci of animal origin. Int $\mathbf{J}$ Med Microbiol 303:338-349

Zhang K, McClure J, Elsayed S, Louie T, Clony JM (2005) Novel PCR assay for characterization and concomitant subtyping of staphylococcal cassette chromosome mec Types I to V in methicillin-resistant Staphylococcus aureus. J Clin Microbiol 43:5026-5033

Zhang L, Thomas JC, Miragaia M, Bouchami O, Chaves F, d'Azevedo PA, Aanensen DM, de Lencastre H, Gray BM, Robinson DA (2013) Multilocus sequence typing and further genetic characterization of the enigmatic pathogen, Staphylococcus hominis. PLoS ONE 8:e66496 